\title{
Innovative startups 2012
}

\author{
Brady Huggett
}

$\triangle$ listing of the top 10 innovative startups receiving the largest Series A Arounds in 2012 is made up entirely of companies from the US, underlying how these enterprises find it easier to raise risk capital. The top five is dominated by firms located in the traditional biotech hubs of San Francisco and Cambridge, Massachusetts.
In fact, a look at the broader life science startup sector shows that more than two-thirds of A rounds in 2012 went to US companies (Fig. 1). Regarding investors, Third Rock Ventures was sole backer for two of the largest A rounds, and the year saw a persistent presence of corporate venture arms: Novo, Novartis and Roche all made Table 1.

Table 1 Top 10 A rounds in 2012 for innovative startups

\begin{tabular}{|c|c|c|c|c|}
\hline Company & Amount (millions), date, investors & Academic founders & Other & Technology \\
\hline $\begin{array}{l}\text { Global Blood } \\
\text { Therapeutics, } \\
\text { San Francisco }\end{array}$ & $\begin{array}{l}\$ 40.7,6 / 14 \\
\text { Third Rock Ventures }\end{array}$ & $\begin{array}{l}\text { Matthew P. Jacobson, Andrej Sali and Jack } \\
\text { Taunton, University of California, San Francisco }\end{array}$ & $\begin{array}{l}\text { Charles Homcy, Third Rock Ventures; } \\
\text { Craig Muir, Third Rock Ventures; } \\
\text { David Phillips, cofounder of } \\
\text { COR Therapeutics and Portola } \\
\text { Pharmaceuticals }\end{array}$ & $\begin{array}{l}\text { Using computational biology and } \\
\text { protein-ligand modeling with medici- } \\
\text { nal chemistry and empiric screening } \\
\text { for developing therapeutics for genetic } \\
\text { blood disorders }\end{array}$ \\
\hline $\begin{array}{l}\text { Moderna } \\
\text { Therapeutics, } \\
\text { Cambridge, }\end{array}$ & $\begin{array}{l}\$ 40,12 / 6, \\
\text { Flagship Ventures, } \\
\text { private investors }\end{array}$ & $\begin{array}{l}\text { Robert Langer, Massachusetts Institute of } \\
\text { Technology; Derrick Rossi, Harvard University }\end{array}$ & $\begin{array}{l}\text { Noubar Afeyan, Flagship Ventures; } \\
\text { Stéphane Bancel, previously CEO of } \\
\text { bioMérieux }\end{array}$ & $\begin{array}{l}\text { Developing first-in-class chemically } \\
\text { modified mRNA therapeutics }\end{array}$ \\
\hline
\end{tabular}

Massachusetts

\section{MyoKardia, $\quad \$ 38,9 / 20$, Third}

San Francisco Rock Ventures

Allakos, San

Francisco

$\$ 32,12 / 17$, Novo Ventures, Alta Partners, RiverVest Venture Partners, Roche Venture Fund

Cerecor, Baltimore $\$ 22,4 / 4$, accredited investors, company directors

BioMotiv, Cleveland $\$ 21,9 / 5$, University Hospitals (UH), Harrington family

Atterocor, $\quad \$ 16,8 / 3$, Frazier Healthcare

Ann Arbor, Michigan Ventures, 5AM Ventures

Thesan $\$ 16,10 / 30$, Novo Ventures,

Pharmaceuticals, Novartis Venture Funds

San Clemente,

California

Vascular

Pharmaceuticals,

\$16M, 9/12, Intersouth Partners, David R. Clemmons, University of North MPM Capital

Carolina at Chapel Hill

Leslie Leinwand, University of Colorado

Not applicable

Boulder; Christine Seidman, Harvard; Jonathan

G. Seidman, Harvard;

James A. Spudich, Stanford University

Not applicable

Solomon H. Snyder, Johns Hopkins University; Barbara Slusher, Brain Science Institute Drug entrepreneurs NeuroTranslational Discovery Program

Board of Managers: Achilles A. Demetriou, UH; Jonathan S. Stamler, UH Harrington Discovery Institute; Ronald G. Harrington and Robert S. Reitman, entrepreneurs and philanthropists; Robert W. Keith, CEO, BioMotiv; David C. U'Prichard, CSO, BioMotiv

Developing mutation-specific sarcomeric allosteric modulators for cardiomyopathies

Christopher Bebbington, more than

Developing antibody therapeutics based on the dysregulation of the T helper type 2 immune response

Chapel Hill, North

Carolina

ImaginAb,

Inglewood,

$\$ 12.5,3 / 26$, Novartis Venture

Robert Reiter, University of California, Los Funds, Mérieux Développement, Angeles (UCLA) Anna Wu, UCLA and the Nextech Invest, Cycad Group, Beckman Research Institute of the City of Julia Owens, formerly at Lycera Corp. Raili Kerppola, ONL Therapeutics

Daniele Piomelli, University of California, Irvine Not applicable and the Italian Institute of Technology

\section{Developing drugs for the nervous} system including cough and schizophrenia

Accelerator for aligning capital and collaborations with physician inventors

Hope; Tove Olafsen, UCLA

\section{Not applicable \\ Developing monoclonal antibody with activity against proteinuria and histologi-}

Christian Behrenbruch, serial entrepreneur
Lead candidate a topically applied new chemical entity for dermatology expected to enter the clinic in 2013 cal changes in the kidney

In vivo imaging agents for positron emission tomography based on antibody fragment technology

Source: $\mathrm{BCIQ}$ : BioCentury Online Intelligence; company websites

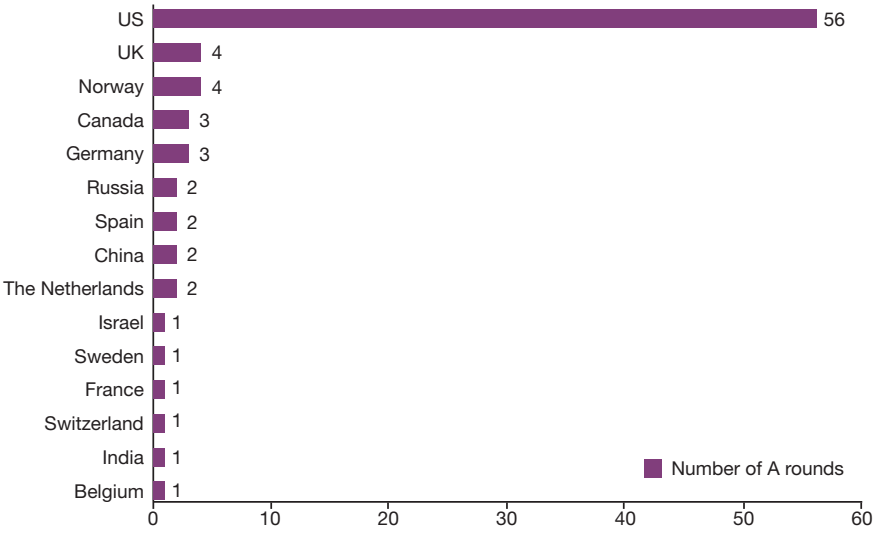

Figure 1 Startups by country, 2012. Source: BioCentury Online Intelligence (BCIQ)

\section{First Rounders Podcast:}

\section{Henri A. Termeer}

Termeer was named CEO of Genzyme in 1983. Under his guidance the firm produced several life-saving drugs and became one of the flagships of the biotech sector, particularly in developing drugs for rare disease. Nature Biotechnology spoke to Termeer about the early years at Genzyme, the company's acquisition by Sanofi in 2011 and his advice to bioentrepreneurs. http://www. nature.com/nbt/podcast/index.html.

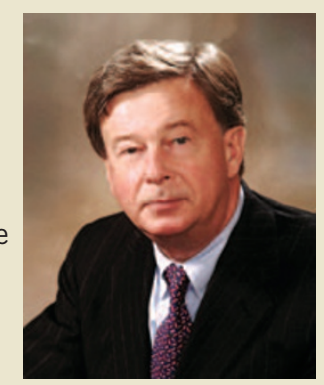

